\title{
Indonesian Single Rod Implant: A New Breakthrough
}

\author{
Eka Rusdianto Gunardi* \\ Department of Obstetrics and Gynecology, Universitas Indonesia, Indonesia
}

*Corresponding author: Eka Rusdianto Gunardi, Department of Obstetrics and Gynecology, Faculty of Medicine Universitas Indonesia, Indonesia.

To Cite This Article: Eka Rusdianto Gunardi. Indonesian Single Rod Implant: A New Breakthrough. Am J Biomed Sci \& Res. 2019 - 1(6). AJBSR. MS.ID.000558. DOI: 10.34297/AJBSR.2019.01.000558

Received: March 15, 2019 | Published: March 20, 2019

\section{Opinion}

Implant as a contraceptive device was begun for the clinical trial in 1968 in Santiago, Chile. The tube contained polydimethylsiloxane (silastic or silicon) which was filled by chlormadinone acetate as synthetic gestagen or progestin. However, the trial was stopped due to toxicity in animal experiments [1]. Several years later, six rods implant containing megestrol acetate was run for clinical trial in Chile, India, and Brazil; unfortunately, it stopped because of ectopic pregnancy as consequence of failure [2]. In 1980, there was a trial to compare six- (Norplant $₫$ ) and two-rod-implant (Norplant- $2 \AA$ ) containing levonogestrel (LNG) and continued by the development of Jadena ${ }^{\circledR}$ marketed in Indonesia which was officially accepted by FDA in 1996 [3,4]. Indonesian implant developed single rod marketed as Indoplant ${ }^{\circledR}$ containing $150 \mathrm{mg}$ LNG and Monoplant ${ }^{\circledR}$ consisting of $160 \mathrm{mg}$ LNG. Monoplant ${ }^{\circledR}$ was estimated for 3 years of effectiveness as contraceptive [5]. Therefore, this article would like to present a novel idea in the advancement of Monoplant ${ }^{\circledR}$ for consideration for publication in American Journal of Biomedical Science \& Research.

This single rod implant is now undergoing for research in the third stage of clinical trial because prior clinical trial showed good promise in its efficacy. There are some reasons in which monoplant will bring positive impact. Monoplant ${ }^{\circledR}$ as new breakthrough for long-term contraceptive method in Indonesia is expected to be effective and efficient contraception in Indonesia. Levonogestrel which had been used in Indonesia for more than 30 years was proven to be very efficient substance; thus, it could reduce the cost of contraceptive spent especially in universal health coverage era [5].

Indonesia as the fourth largest population in the world had growth rate of $1.49 \%$ between 2000 and 2010. Family planning through long term contraceptive method is the key to reduce this growth effectively [5]. In Indonesia, injectable (50.8\%) still became more favorable among people using contraception; followed by pill (21.2\%) and implants (8.2\%) [6]. Therefore, to push the implant prevalence rate in Indonesia, it should be integrated well to culture and society. Since the use of implant is familiar to many people of Indonesia and have been well known to society, it will not be hard to spread the use of Monoplant ${ }^{\circledR}$.

Monoplant ${ }^{\circledR}$ will only have single rod to insert in the upper arms causing the advantages of insertion and removal easily. Apart from that, the efficacy and safety are similar to Indoplant ${ }^{\circledR}$ (two rod implant that currently marketed nationwide) [7]. In terms of efficacy a quantitative measurement has been done. We measured Levonogestrel concentration in serum up till 6 months of insertion. The result is LNG serum concentration is far above the contraceptive level with mean of $337.5 \mathrm{pg} / \mathrm{ml}$ ( $\min 200 \mathrm{pg} / \mathrm{ml}$ ), giving suitability in Indonesian people and proving its efficacy [8].

We believe that this advancement will bring a new hope to increase the efficacy of national contraception program. Besides, we hope that later on, we will publish the third clinical trial to share a new breakthrough and knowledge in contraceptive technology and method.

\section{Conflict of Interest}

There is no conflict of interest declared and this manuscript has not been published or under consideration for publication elsewhere.

\section{References}

1. Hill R, Averkin E, Brown W, Gagne WE, Segre E (1970) Progestational potency of chlormadinone acetate in the immature beagle bitch: Preliminary report. Contraception 2(6): 381-390.

2. Shoupe D, Mishell DR (1989) Norplant: subdermal implant system for long-term contraception. Am J Obstet Gynecol 160(5 Pt 2): 1286-1292.

3. Sivin I (1997) Clinical performance of a new two rods LNG contraceptive implant: A three-year randomized study with Norplant implant as controls. Contraception 55(2): 73-80.

4. Leiras Oy (1997) Norplant ${ }^{\circledR}$ concensus statement. Finland.

5. Gunandi E, Affandi B, Muchtar A (2011) Monoplant ${ }^{\circledR}$ the Indonesian Implant: The Overview of Implant and Its Development. Indonesian Journal of Obstetrics and Gynecology 35(1): 40-46. 
6. Indonesia Investments Population of Indonesia [downloaded $11^{\text {th }}$ March 2019].

7. Family Planning 2020 FP 2020 momentum at the midpoint 2015-2016 [downloaded 11th March 2019].

8. Gunardi E, Ballo F (2017) The Efficacy of Monoplant ${ }^{\circledR}$ and Indoplant ${ }^{\circledR}$ as Contraceptive Methods: A Comparative Study. Indonesian Journal of Obstetrics and Gynecology 5(2): 94-98.
9. Gunardi E, Affandi B, Juliaan F (2011) Levongestrel Concentration in a Single Rod Implant Users for Six Months. Indonesian Journal of Obstetrics and Gynecology 35(3): 122-127. 